\title{
A Critical Discourse Analysis Approach to Othering: Depiction of the Syrian Refugee Experience in Turkish Children's Literature
}

\section{Abstract}

This paper is a critical examination of discursive strategies of othering in three refugee-focused books in Turkish children's literature written after the onset of Syrian civil war. Drawing upon Van Dijk's ideological analysis, eliciting the representation of "us vs. them" in a network of semantic and formal structures, the study has two closely related main aims. The first is to show how children's literature, as a significant conveyor of norms, values, and ideology, provides fertile ground to examine power relations. The second is to identify discursive strategies of othering, which categorize and underscore group-based differences by attributing negative characteristics, in three Turkish children's books about the Syrian war. Findings demonstrate that negative representation of the Other is foregrounded by actor description, lexicalization, and implicitness within the framework of semantic structures. Formal structures resonate with topoi under the umbrella of argumentation and rhetoric, with special emphasis upon allegory.

Keywords: Othering, critical discourse analysis, negative representation of Other, Syrian refugees, Turkish children's literature

\section{Introduction}

It is well-established and widely accepted that children's literature constitutes one of the largest and most important social domains for encapsulating and inculcating the culture, morals, and values of a society. Indeed, it is an "ideological minefield" (Hunt 186). "Because children's literature is one of the earliest ways in which the young encounter stories, it plays a powerful role in shaping 
how we think about and understand the world" (Reynolds, Children's Literature 4). According to Stephens "fiction must be regarded as a special site for ideological effect, with a potentially powerful capacity for shaping audience's attitudes" (3). Hence, children's literature has an ideological purpose, which it achieves by shaping, fostering and transmitting a positive or negative perception of certain ideologies and moral assumptions. In addition to its ideological baggage, children's literature can promote a critical perspective which leads to capable, socially aware young readers, "the potential adults" (Beauvais 20) "who can interrogate their surroundings and decide what they wanted to think and believe" (Reynolds, Left Out 2). Children's literature, thus, plays a pivotal role regarding socialization, literacy development, and critical engagement with texts because it allows questioning and comparison of visual and textual elements.

In this respect, the role of discourse in the (re)production of an ideology is the key point in analyzing and criticizing social problems and processes, which leads to the uncovering of the discursive means of mental control. "Discourses are not simply innocent forms of language use or marginal types of verbal social interactions. Rather, they have a fundamental impact on the social cognition of group members, on the acquisition, confirmation, and uses of opinions, attitudes, and ideologies underlying social perceptions, actions and structures" (Van Dijk, "Elite Discourse" 3). Building on this notion, Critical Discourse Analysis (henceforth CDA) considers language as an instrument capable of shaping and manipulating ideologies, thoughts, and feelings through texts. This approach proposes that the constructive effect of discourse affects social identities, power relationships and systems of knowledge and belief. "Therefore the central questions are: who can say or write to whom in what situations?" (Van Dijk, "Discourse Analysis" 21). Hence, this study proposes CDA as a research paradigm capable of examining the link between children's literature and the underlying othering, power, and control structures. In this regard, Turkish children's literature on the Syrian war is considered a significant site for investigating the socio-cultural experiences of underrepresented groups. The importance of this literature is twofold. First, it offers a readily available source of data on the ideological orientations of children's literature problematizing immigrant/refugee issues, allowing exploration of the social and political conditions in a particular society at a particular time. Second, a pluralistic diversity paradigm is produced, 
legitimized, and consumed in children's literature by deploying a plot, setting, and characterization within a realistic realm.

In line with the foregoing considerations, the primary aim of this study is to examine the reflections of refugee issues in a specific literature with respect to discursive enactment of othering and Otherness. This article presents an ideological analysis of discursive properties with respect to othering, and us vs. them discourse. The approach taken is Van Dijk's ideological analysis, based on his ideological square and his framework of analysis on migration and immigrant discourse, which encapsulates semantic and formal structural categories. A corpus was compiled to obtain a balanced and representative overview of books that spotlight and instrumentalize the refugee issue in Turkey. This led to the selection of three Turkish children's books published after the outbreak of Syrian Civil war: Tombik Balık: Denizler Hepimizin [The Plumpy Fish: We All Own the Sea] (Bektaș 2017), Kuș Olsam Evime Uçsam [I Wish I Was a Bird and Flew Home] (Öztürk 2017), Juju Beni Unutma [Juju, Don’t Forget Me] (Sezer 2015).

\section{Background}

The massive arrival of migrants in Europe can be considered as an external trigger deriving from two catalytic events: the 2011 Arab Spring, which resulted in toppling of Gaddafi, and the occurrence of 2015 refugee crisis following the outbreak of the Syrian civil war. Since the onset of Syrian civil war, according to UNHCR, more than 7.1 million Syrians reside in host countries, and a total of 6.5 million Syrians are internally displaced (2021). The statistics of Republic of Turkey Ministry of Interior, Directorate General of Migration Management indicate that, as of 21 April 2021, more than 3.6 million Syrians were registered with a legal status of under temporary protection (2021).

The refugee crisis led to a political crisis regarding migration and border policies, primarily in the European Union. The slow and inadequate responses of the European Union toward the massive arrival of refugees were primarily derived from

the belief that the multi-layered border regime established over the previous decades - the programmes of externalisation stretching outwards, the rearmament of the EU external border by 
both technological and military means, the inward deployment of bordering technologies such as

digital, biometric databases and the well-developed legal frameworks such as the Schengen Acquis, the Common European Asylum System (CEAS) including the Dublin regulation - would guarantee ample means to inhibit migratory movements towards Europe. (Hess and Kasperek 49-

However, it became clear that the existing mandates and legislation of EU were inadequate for the scale and complexity of the 2015 migrations. The framework of the neoliberal economic paradigm outlined by the free movement of goods, services, capital, and workers did not commit to global freedom for those outside of the EU; the EU refugee policy implemented the policy of regionalism, i.e., refugees are kept in their region of origin. According to Hess and Kasperek:

three paradigms were enacted within the European border regime. First, to the outside, a paradigm of "remote control" and externalisation. Second, a paradigm of a fortified, yet smart external border through technology, digitalisation and biometrisation ... and a third one, namely an internal regime steeped in the institution of asylum and put into practice through the Dublin/Eurodac regulations, aiming at the immobilisation of migrant populations within the European territory. (52)

Turkey's candidacy for the full membership of EU heightened the urgency of its cooperation with the EU in border regions. Moreover, Turkey's strategic geographical location makes it a gatekeeper and transit country for millions of refugees aiming for European countries through border crossings over sea, river, and land. In addition to the Evros River, the natural border between Turkey and Greece, the Aegean Sea became the primary irregular maritime migration corridor and claimed the lives of hundreds, including scores of children. Turkey's first reaction to large numbers of Syrians crossing its borders was to implement an open-door policy. Initially, refugee camps were built along the borders, and humanitarian assistance was provided in coordination with UNHCR. However, as the war and arrival of Syrian migrants continued with no end in sight, Turkey gradually switched to incorporate temporary protection, non-refoulment, and humanitarian assistance into its response. İçduygu and Millet summarized Turkish domestic policy for Syrian refuges as follows: 
Turkey's domestic policy towards Syrian refugees has evolved over time, going through a stage of admission and settlement (2013 - 2015), stabilization (towards the end of 2015), integration (throughout 2016) and is potentially heading towards a naturalization period (the debate on access to Turkish citizenship for Syrian migrants is ongoing). (4)

In order to externalize irregular maritime traffic through the Aegean corridor, the EU agreed with Turkey on a Joint Action Plan (2015) to keep refugees within Turkish borders.

According to the agreement, in return for $€ 3$ billion and visa liberalization for the Schengen area for Turkish citizens, Turkey would enforce its European borders and improve the conditions for Syrian refugees in the country. For Okyay and Zaragoza-Cristiani, "[t]his agreement is the outcome of a bargaining process in which Turkey gained considerable leverage from its position as a 'gatekeeper' situated between Syria and an increasingly 'immigration-averse' and securitized EU' (51). However, EU-Turkey relations declined after the deal failed to live up to expectations. The changed atmosphere in Turkey following the 2016 coup attempt and the EU's failure to fulfill its promises led to disagreements and resentment on both sides.

According to UNHCR, "Turkey has been progressively implementing a policy of inclusion and harmonization" (2021). Cuevas et al. in World Bank report on vulnerability and protection of refugees in Turkey pointed out that "refugees in Turkey can obtain identity cards, with which they can access health care in government facilities and enroll in schools. Working-age refugees can also potentially obtain work permits." However, the report continued "[n]otwithstanding this, other significant barriers remain to increase coverage of these services, particularly with regard to work permits and schooling" (Cuevas et al. 5).

From the standpoint of acceptance of refugees at home, findings are far from the uniform. The governing Justice and Development Party (Adalet ve Kalkınma Partisi - AKP) engaged in a humanitarian discourse "by reference to narratives of "historical and geographical necessities," "religious fraternity," and "ethnic kinship" (Toğral Koca 56). By the same token, Polat asserts that "The AKP's discourse on Syrian refugees has become intertwined with its positive selfrepresentation as the defender of all oppressed people (mazlum) and its attempts to reconstruct the Turkish nation along more Islamic lines" (500). An oppositional public discourse also emerged, 
which resonates with the position of the opposition party and secularist-elitist segments of Turkish society, depicts Syrian refugees as an economic and social burden, and a group with cultural traits incompatible with the socio-cultural fabric of Turkey. In a similar vein, Onay-Çokar argues that

'burden' discourses refer to the overall load the Syrians have on the Turkish economy, and their negative effects on daily Turkish life. The discourse of 'burden' also depicts 'Turks are victims suffering because of the Syrians,' which perpetuates such modalities as the immigrants taking advantage of Turkish public health, governmental, and business resources. (383)

This polarization in public opinion was intensified by Turkey's strategy of opening the doors for millions of refugees, leading to a shift from its former policy of Kemalist nationalism toward multiculturalism. Kemalism had been enacted since the early republican era (the 1930s), when the emphasis of insular Kemalist nationalism was on the unity of language, ethnicity, and culture, promoting a narrow definition of Turkishness as an umbrella identity, and ignoring all subcultures and ethnic groups. In contrast, through the implementation of inclusion and harmonization policies, AKP has embarked on a social engineering based on pan-Islamism.

\section{Theoretical Framework}

Van Dijk's tripartite approach involves cognition, society, and discourse. In this approach, an ideological analysis of discourse requires an interdisciplinary approach; only such an approach can elucidate ideologically laden group polarization in text structure, which is a critical site for the negotiation of othering as a natural cognitive process prevalent in intercultural encounters. According to Van Dijk:

ideologies have many cognitive and social functions. First of all, they organize and ground the social representations shared by the members of (ideological) groups. Secondly, they are the ultimate basis of the discourses and other social practices of the members of social groups as group members. Thirdly, they allow members to organize and coordinate their (joint) actions and interactions in view of the goals and interests of the group as a whole. Finally, they function as the part of the sociocognitive interface between social structures (conditions, etc.) of groups on the one 
hand, and their discourses and other social practices on the other hand. ("Ideology and Discourse Analysis" 117)

Thus, ideologies have a substantial impact on personal cognition of group membership, as they "represent the characteristic identity, actions, aims, norms, and values of a group, and may control more specific attitudes, e.g., about immigration, integration or adaptation of migrants" (Van Dijk, "Discourse and Migration" 242). The indirect links between cognitive and interaction levels can be brought to the surface by employing social representations, along with attitudes and ideologies, to contribute to the formulation or confirmation of collective social attitudes of ideologies. Mental representations of individuals during such social actions and interactions are built along "us vs. them" dimensions as models, which "control how people act, speak or write, how they understand the social practices of Others" (Van Dijk, "Discourse Analysis" 20). If mental models of a political issue or a social event, in our case, migration and refugee issues, are governed, naturalized, and legitimized in the cognitive maps, then "they may be generalized and abstracted from to form social representations such as knowledge, attitudes and ideologies" (Van Dijk, "On the Analysis of Parliamentary Debates" 78), because "migration discourse not only may be about migration or its many aspects, but also be a constituent part of migration as a phenomenon" (Van Dijk, "Discourse and Migration" 230).

Out-group derogation and in-group celebration in a society are typical consequences of migration/refugee discourse which pave the way for othering. Van Dijk's emphasis on polarized structure, reflecting competing or conflicting groups and differentiation in in-groups and out-groups, entails the control of discourse contents which often feature the ideological square:

Emphasize Our good things

Emphasize Their bad things

De-emphasize Our bad things

De-emphasize Their good things ("Politics, Ideology" 734)

In his frame, Van Dijk designates positive self-presentation or in-group favoritism as a semantic macro strategy for impression management and facework, notions put forward by Goffman Schlenker, Brown and Levinson. These notions offer a conceptual vehicle for improving 
understandings of human interaction and development. Van Dijk underlines Other-negative presentation as another semantic macro strategy, regarding in-group/out-group divisions with respect to good vs. bad, superior vs. inferior, "us vs. them". In other words, in-group vs. out-group polarization makes extensive use of ideological manipulations employing "us vs. them" dichotomy, with the aim of expressing, enacting, sustaining, and inculcating in-group/out-group differentiation, in which some groups are projected as Others. Apart from his polarized ideological avenue, Van Dijk put forward a framework in which

various semantic and formal levels of discourse are systematically examined for those structures or devices that specifically express or influence beliefs about minorities or immigrants, or that contribute to the various social and political acts involved in the reproduction of political racism.

("On the Analysis of Parliamentary Debates" 85)

The analysis section will enlighten negative other-presentation by discussing discursive strategies underpinned by the abovementioned linguistic realizations, as employed by characters in the selected texts for Turkish children.

\section{Data and Methodology}

According to Van Dijk, "ideologies are organized by a general schema consisting of the basic categories that organize the self and other representations of a group and its members" ("Critical Discourse Studies" 79). These systematic means allow the examination of discourse at various levels to expose the indoctrination of ideologies in discriminatory discourse. Van Dijk's frame deals with a social system of inequality covering two main subsystems: social and cognitive. The social subsystems include, at the micro-level, a system of discriminatory activities, and at the macrolevel, a group dominance that displays itself either in the form of in-group favoritism or out-group derogation. In addition, there is a cognitive subsystem of fragmented, discriminative, racist ideology controlling specific attitudes. To establish an enhanced integrated framework of analysis, the immigration-focused framework adapted from Van Dijk is integrated into a network of semantic and formal structures intermingled with his ideological square. This combined approach is used to 
designate othering strategies in the emergent Turkish children's literature on the topic of the Syrian civil war.

The corpus was compiled to obtain a balanced and representative overview of books that spotlight and instrumentalize Otherness and Othering. To this end, our data set consists of three children's books in Turkish published after the outbreak of the Syrian Civil war. A sentence-level analysis was conducted to identify extracts exemplifying Otherness and Othering. These extracts were then matched with Van Dijk's enhanced framework, which encapsulates his semantic and formal categories. The three books published between 2015 and 2017 in our corpus are summarized as follows $!^{[1]}$ Table 1. Details on the books in the dataset

\begin{tabular}{|c|c|c|c|}
\hline BOOK & PLOT & POINT OF VIEW & PROTAGONIST \\
\hline $\begin{array}{l}\text { T1- Bektaş, Habib. Tombik Balık: } \\
\text { Denizler Hepimizin [The Plumpy Fish: } \\
\text { We All Own the Sea]. Tudem, } 2017 .\end{array}$ & $\begin{array}{l}\text { The book, written in half verse and } \\
\text { half prose, depicts the journey that } \\
\text { two young fish embark on when they } \\
\text { leave home in search of different } \\
\text { sights. They witness refugees in the } \\
\text { sea and realize that there are borders } \\
\text { and restrictions in the world. }\end{array}$ & Third person & Tombik and Benli \\
\hline $\begin{array}{l}\text { T2- Öztürk, Güzin. Kuş olsam Evime } \\
\text { Uçsam [I Wish I Was a Bird and Flew } \\
\text { Home]. Tudem, } 2016 .\end{array}$ & $\begin{array}{l}\text { The story details Beşir and his family } \\
\text { as they embark on their journey to } \\
\text { Turkey from Syria. Beşir narrates his } \\
\text { life in a refugee camp and then in a } \\
\text { ghetto in Turkey. He reflects his } \\
\text { feelings of being displaced and Other. }\end{array}$ & $\begin{array}{l}\text { 1st person singular } \\
\text { (Protagonist) }\end{array}$ & Beşir \\
\hline $\begin{array}{l}\text { T3- Sezer, Ciğdem. Juju Beni Unutma } \\
\text { [Juju, Don't Forget Me]. Bilgi Yayınevi } \\
\text { Çocuk Kitaplığı, } 2015 .\end{array}$ & $\begin{array}{l}\text { Juju is a Syrian refugee girl who fled } \\
\text { her country with her family of four } \\
\text { due to civil war. She uses a tape } \\
\text { recorder to record her feelings of } \\
\text { Otherness. One day, she sees a } \\
\text { picture of her friend Azer in the } \\
\text { newspaper and writes to him. After } \\
\text { receiving a reply, Juju looks to the } \\
\text { future with hope and conveys a sense } \\
\text { of optimism. }\end{array}$ & $\begin{array}{l}\text { 1st person singular } \\
\text { (Protagonist) }\end{array}$ & Juju \\
\hline
\end{tabular}

In the following section, further details from the stories are provided and discriminatory rhetoric in the books is contextualized through the elaboration of characterization.

\subsection{Details about the Books}

Text 1: Tombik Balık: Denizler Hepimizin [The Plump Fish: We All Own the Sea] by Habib Bektaș The story of two fish protagonists, Tombik (Plump) and Benli (Spotty), raises readers' awareness about the difficulties of living in the sea in a world with borders and restrictions. The two close friends - having learned all there is to know about the open seas and the human world from Octopus the Wise - set off and swim to the Aegean Sea, a well-known refugee escape route to Greece. During their long journey, they encounter Syrian refugees and help them navigate to 
Greece. They also come across a little green fish whom they help with the seven big sharks that prevent it from crossing from the freshwater zone to the seawater. The story shows the importance of achieving self-determination in lifestyle and choice of home using this stirring rallying cry:

\author{
Just as we have lived until now \\ In the waters of our beautiful delta \\ We shall, of course, carry on living as such, \\ Yet it is downright great to know \\ That we could also live in other waters \\ If we ever wanted to, life is beautiful. (38)
}

At the end of the story, after various adventures, the two fish attain the wisdom of moral righteousness, justice, self-determination, freedom and happiness.

Text 2: Kul Olsam, Evime Uçsam [I Wish I Was a Bird and Flew Home] by Güzin Öztürk This award-winning novel (Best Novel in the 2015 Tudem Literature Contest) portrays Beșir and his family's migration from war-torn Aleppo to Hatay, Turkey, after the death of his elder brother in the Syrian war. Before they set out, Beșir puts some soil from home in his pocket: "The soil smells like homeland," says Beșir. A linden seed in his soil starts to talk. This seed, named Tartus, metonymically stands for what is left behind in Syria. Beșir keeps the seed and, when they reach the refugee camp, plants it in a tin can. His narrative sheds light on tragedies revealed in the stories of children he meets there. Beșir's narrative is woven around nightmares highlighting his fear and anxiety in the face of his deep longing to go back home. Beșir's gripping story of flight and survival in Turkey also unveils a poignant discourse of hostility and xenophobia. In İzmir, a metropolis in Turkey, he leads a segregated life in a refugee ghetto, as if imprisoned by invisible walls. In the rather grim reality of life in İzmir, he depicts a slum community, organized through ingroup solidarity and helped by local administration bodies. His eagerness to learn about the wider world causes him to run away and embark on adventures in which he is usually treated as Other. The book ends with Beșir's letter to one of his friends, Zehra, back in the camp, in which, despite his resentment toward life and the host society, he expresses great hope and describes some of his happier times. 


\section{Text 3: Juju Beni Unutma [Juju Don’t Forget me] by Çiğdem Sezer}

Juju is the first-person singular narrative of a Syrian refugee girl talking on a tape recorder gifted by Cengiz Abi ("Brother Cengiz"), a university student volunteer in a refugee camp in Turkey. Juju and four other members of her family emigrated from Syria to Turkey. Without going into the details of how they fled, she narrates her adaptation process in Turkey. Her younger sister, Teslime, refuses to speak as a result of the war trauma. Juju clearly remembers her memories of the war in her homeland. Traumatized, she tells us of the bombs that killed her granny, her best friend Fatima, and her classmates, and she longs for her remembered past. Juju's narration, which problematizes dislocation and uncertainty from the perspective of a young girl, demonstrates her unsettling feelings and her questioning of dark realities of inequality and borders, "Human beings shared the world. The territory which falls to our share is called a country. Why can't people live wherever they want?" (6).

In the course of the story, we learn that Juju and her family eventually move from the refugee camp to the city. Her father is now a janitor in an apartment block, and her mother, a charwoman. Their home on the basement floor of the building symbolizes the lowest layer of social strata below the other residents, representing Turkish society. She tells us about the residents' behavior toward her family and other Syrians. Reflecting the mosaic nature of Turkey's population, some are xenophobes, lacking any sensitivity to recognize common grounds of humanity, while others adopt a humanitarian discourse with pro-solidarity rhetoric.

All three books have happy endings, full of hope and optimism for integration, recognition and projections of a brighter future.

\section{Analysis}

\subsection{Semantic Structures}

\section{Actor Description}

The consequences of self-categorization foreground both perceived similarities between the self and Other in-group members (us), and differences between the self and out-group members 
(them). These accentuations cover all the schemas, beliefs, behavioral norms, values, attitudes, styles of speech, and other properties believed to be associated with an intergroup categorization. In our dataset, it is possible to see polarizing differences, such as us vs. them, highlighted in the use of inclusive and exclusive pronouns and possessives (i.e., "us vs. them", "we vs. they", "ours vs. theirs"). The rhetorical perspectives created through the employment of these binaries resonate with the polarization of ingroups and outgroups. The use of "they" denotes detachment from the group, as a demonstrative of distance. In contrast, "we" creates a sense of unity, binding the speaker(s) and addressees into a group. This polarization is visible in the following example:

Context: Beșir expresses his impressions about his new life in a ghetto located in İzmir

[1] "I think it is written all over our face that we are Syrian. Some Turks do not approach, they fear us. Some of them help. There are children playing with us. We could barely communicate with them." (Öztürk 96)

In excerpt [1], the "our," "we," and "us" are inclusive of the speaker, the refugee Beșir, and the "them" and "they" refer to Turkish people. Beșir's internalized social categorization reflects his assessment of the in-group and out-group distinction. Two related perspectives, seeing the self through the lens of the out-group prototype as a refugee, and denoting Others as out-group, apart from the host society, are particularly evident in the use of naming strategies, using generalized umbrella terms, to contrast Türkler ("Turkish people") with Suriyeliler ("Syrians"), Suriyeli çocuklar (“Syrian children”), mülteciler (“refugees”) and sığınmacılar (“asylum seekers”).

\section{Lexicalization}

Meaning can be variably constructed in various ways through different words, depending on the position, role, aims, and political stance of the speakers. As Van Dijk suggests, "opinions may be conventionalized and codified in lexicon" ("Discourse Analysis as Ideology" 205). To reinforce and legitimate the ideology, specific words or expressions are chosen from a wide range of choices to characterize persons, groups, social relations, and attitudes that generate conflict.

Lexicalization is a powerful tool for the agents directing child reader's attitudes, as it can be employed either to glorify in-group traits or derogate the other group by presenting it as an enemy, evil, or a threat. Overt derogation of othered groups is a common practice of Othering and 
exclusion through nominalization and lexical strategies with respect to refugees and immigrants. Overt derogation of othered groups is a common practice of Othering and exclusion through nominalization and lexical strategies concerning refugees and immigrants. Negative lexicalization in the use of arsız ("cheeky"), hırsız ("thief"), dilenci ("beggar"), and baș belası ("troublemaker") conveys strong anti-refugee rhetoric, reducing them to a monolithic whole of undifferentiated individuals with negative traits. The following examples of the negative reactions of Turkish people include passing demeaning and insulting remarks and shouting.

Context: The old man living at number 3 reacts to the Syrian woman who tries to take away a discarded cooker.

[2] "The state gives you everything. You also beg without shame. You are cheeky, cheeky!" (Sezer 47)

Context: Juju climbs a tree. The lady living in number 1 intervenes harshly.

[3] "Get out of that tree! You have already given us enough trouble. Go back to wherever you come from." (Sezer 17)

As illustrated in the abovementioned examples, the building where Juju and her family live reflects social diversity in Turkey. Different groups of residents representing opposing camps on the refugee issue employ contesting and challenging public discourses, built around negative and positive attitudes. In all three books, these competing discourses are associated with the themes of goodness and badness, and positive as well as negative contacts. Some people cannot accept their arrival or tolerate this new situation in the host country, as illustrated in this extract describing the cruel treatment of refugees: "Brother Cengiz said to me there are good and bad ones. "If we are bad, the good is lost" he says. Why do I have to be good? Why didn't the neighbor who saw Buğra beating me say anything? Why wasn't she nice?" (Sezer 28).

Negative presentations and discriminatory actions are sometimes given through the narration of the refugee experiences.

[4] "We cannot go to school because there is no school for Syrian children to go to. I wish we could go. I think it is hard to be a Syrian here. We never go out of the neighborhood. Our clothes are shabby. Since we have no money, we cannot buy new ones. I told Halebie that we are Syrian, it is 
written all over our face. He asked me how. I do not know that it is understandable. Nobody approaches us. I have no Turkish friends except Samet. Sometimes we start to play with other Turkish children. Moms come and grab them and take them away. They are also scared." (Öztürk 115)

As captured in the above-mentioned example, Beșir's feelings of being faced with segregation and discrimination are outlined in his letter to Zehra, in which he explores his sensitivity about his memories of his life in Syria compared with his experiences in Turkey. Addressing discrimination is managed through the voices of protagonists encountering discursive othering strategies.

Implicitness

For Van Dijk,

one of the most powerful instruments in the critical study of discourse is the systematic analysis of implicitness. ... The text is like an iceberg of information of which only the tip is actually expressed in words and sentences. The rest is assumed to be supplied by the knowledge scripts and models of the media users, and therefore usually left unsaid. (Racism and the Press 181)

Implicitness is a discursive strategy that results in the inference of information by the recipients, as based on shared knowledge and attitudes. In other words, the inevitability of interpretation leads the writer to exploit this for persuasive purposes, appealing to the reader's value judgments by conveying a covert message, stimulating the reader to read between the lines for the intended meaning. To illuminate this point, consider the following examples which have implicit baggage: Context: When Juju accompanies her father in his work doing house repairs, the lady at number 2 stops Juju at the door when she attempts to get in.

[5] "Don't come, I just had the house cleaned" she said. Some of them pressed some money into my hand. I was embarrassed. I am not a beggar. I did not go with my father again. (Sezer 19) From her statement, the reader can infer that Juju is assumed to be dirty; the lady living at number 2 implies that if she enters, Juju will soil her newly cleaned house. Dirtiness is a description applied to all immigrants, not just Juju. 
[6] "Where will we live, father?" "In the Postacı neighborhood, my son. There are families like us there. Those fled. Someone in the camp said there are rundown houses where nobody lives." (Öztürk 87)

Narrated representations of immigrant children's experiences, particularly around Otherness, provide an expanded perspective on refugees' living conditions and lifestyle. In the above example, in describing their future house, Beșir's father implies that Syrian refugees can only live in neighborhoods separate from the host society, where they experience impoverished and challenging conditions.

\subsection{Formal structures}

Argumentation

Writing for children fosters socio-cultural values, norms, contemporary morality, and ethics that are taken for granted in a society. This writing encapsulates a hidden persuasive effect whose formal structure is primarily argumentative. Argumentation structures are, therefore, a prominent component of analysis in ideologically laden children's literature.

Topoi

Arguments supporting for and against positions in the refugee issue require topoi as discursive sources. Topoi refers to generative places which enable writers and speakers to create a metonymic effect in cultural meanings using a single word, phrase, or image. For Meyer,

A topos is basically a common knowledge, mutually known and known to be known and shared by the ethos (speaker) and the pathos (audience). As a result, a topos represents the implicit of the rhetorical transaction, what is presupposed by and in it, and this includes rules and judgments that contribute to the drawing of the inference or the establishment of conclusions in the mind of the audience. (448)

Van Dijk spotlights topoi as the core elements of argumentation, since "they represent the common-sense reasoning typical for specific purposes" ("On the Analysis of Parliamentary Debates" 97). These content-related warrants, or conclusion rules, can be expressed in more 
clear-cut terms in the form of conditionals or casual paraphrases, such as "if $\mathrm{X}$, then $\mathrm{Y}$ " or " $\mathrm{Y}$, because X." Despite the rhetoric of humanitarianism and solidarity that dominates all three analyzed texts, there are five topoi that occur in the anti-immigration discourse:Table 2. Topoi in the anti-immigration discourse

\begin{tabular}{|l|l|}
\hline Topoi & Definition \\
\hline Topos of burden & Immigrants/refugees are burden on Turkish economy \\
\hline Topos of unemployment & Immigrants/refugees are the cause of unemployment \\
\hline Topos of abuse & Immigrants/refugees are the abusers of laws and rights \\
\hline Topos of culture & Immigrants/refugees are different regarding customs and values \\
\hline Topos of trouble & Immigrants/refugees are troublemakers \\
\hline
\end{tabular}

Ironically, within all these topoi, a discursive humanistic discourse which counters the antiimmigration discourse crystallizes around the refugee protagonists' wishes, dreams, and letters, as a call for sound integration policies. More precisely, the anti-immigration discourse is exploited to enhance the child readers' perspectives on refugee's social problems and precarious living conditions.

\subsection{Rhetoric}

Using rhetoric in a rather limited and specific sense and underlining its functional role in the overall strategy of group polarization, Van Dijk argues that rhetorical structures "manipulate meaning and the expression and formation of mental models of ethnic events and social representations of ingroup and outgroup" ("On the Analysis of Parliamentary Debates" 100). Discourses woven around Otherness employ vague, ambiguous meanings that are symbolically and metaphorically associated with presupposed information and textual inferences. In such sensitive contexts, rhetorical analyses are used intentionally to communicate discontent. To this end, this section will address the argumentative advantage provided by the employment of allegory from a CDA viewpoint.

Allegory

As a meaning-making strategy, allegory is an evolutionary textual phenomenon prevalent in political discourse. Northrop Frye explains that "we have allegory when the events of a narrative obviously and continuously refer to another simultaneous structure of events or ideas, whether 
historical events, moral or philosophical ideas, or natural phenomena" (12). Allegory, thus, can be considered a device of representation that encapsulates discontinuity, distances, fragmentation, and polarization. Allegorical text is primarily intertextual, constructed by the connection between the immediate context and prior discourses. In other words, in addition to primary meaning, the allegorical text conveys an alternative meaning reflected throughout the text and activates the reader's presupposed information to uncover covert messages. An allegorical text, hence, requires critical reading to cross from the literal to the figurative axis.

Allegorically speaking, $\mathrm{T} 1$ is a story of two fish that fosters a spirit of can-do optimism. However, it can also be taken as a strong criticism of the EU's closed borders and the policy of supporting refugee maintenance in Syria's neighboring countries, despite their lack of resources to bear this burden. Even in the EU-Turkey Joint Action Plan, the priority was border security and mechanisms to keep refugees out. This Eurocentric perspective is allegorized through the story of Tombik and Benli, especially in the section titled "The Shark in the Delta." The writer narrates that, in a river delta, Tombik and Benli come across a little green freshwater fish, and seven big sharks preventing it from entering the salt waters: "'Freshwater fish live in rivers and lakes. As the name implies, they are freshwater fish. Let them not come to our zone!" say the seven sharks" (Bektaș 32). In response, Tombik, a brave red fish, takes the initiative, organizes other little fish, and negotiates with the seven sharks. Addressing the thousands of freshwater fish, Tombik explains: "my friends, there are seven big sharks over there. They will not let your friend enter in the region where they swim. They humiliate him simply because he is a freshwater fish. But he wants to swim in the deep seas. Next time, they will block you as well. Let's teach them a lesson" (Bektaș 35). Then, Tombik suggests that thousands of fish should unite and take the shape of a gigantic shark to scare the seven sharks away. A close reading of this section reveals that the seven-shark union is clearly an allegorical representation of the G7 countries, which obstructed progress in resolving the crisis by insisting on the need for refugees to be supported as close as possible to their home countries. While T1 echoes the refugee crisis, characters employ allegorical embodiment consistent with the actors in Turkey-Syria and the EU triangle. More explicitly, the personified allegorical characters, namely the seven sharks, Tombik, and the green fish, are clearly representative of the G7 countries, Turkey, and a metonymic representation of Syrian refugees, 
respectively. The seven sharks hampering the mobility of green fish display the biased attitudes of seven developed world powers toward the migration of Syrian people. Tombik's initiative and necessary intervention in a critical situation connotes with Turkey's crucial and decisive role in the crisis. The little green fish offers an allegorized representation of Syrians' efforts to reach other lands. Tombik, the little red fish, is a reference to the red Turkish flag, and the little green fish to Islam, in which green color has many traditional associations.

\section{Conclusion}

This study is an examination of discursive strategies of Otherness in Turkish children's literature on Syrian war, more specifically, negative representations of Otherness embedded in semantic and formal structures. First, three semantic categories were discussed: actor description, lexicalization, and the implicitness of the strategies employed to represent negative Other in voicing anti-refugee discourse. The focus then shifted to formal structures which resonate with topoi under the umbrella of argumentation, and rhetoric, with special emphasis upon allegory.

Findings revealed that, in these books, refugees were represented as Other, resonating with the fact that the presence of Syrians is far from being fully accepted at Turkish societal level. Books in the dataset demonstrate two common frames in the portrayal of refugees and immigrants in the Turkish setting, i.e., the positive and negative representation of the Other. Hence, it is possible to distinguish two types of conflicting rhetoric concomitantly used to frame Syrian refugees in public discourse. The first is the humanitarian discourse, which also underscores pro-Islamist president Erdoğan's discourse, intermingled with his positive self-representation as the defender of the oppressed and the promoter of the reappropriation of Muslim identity within Turkish society. The second is the economic and social threat discourse, which resonates with the opposition party's claims and secularist segments of society, associated with a negative tone. In the three books, the primary focus is predominantly on cultural integration related to the refugee issue, within the framework of the humanitarian rhetoric. Syrian refugees are portrayed as humanized victims with distinct names and background, struggling to survive in harsh physical and psychological conditions. The authors approach this universal theme by emphasizing the suffering caused by displacement and otherization. In addition to this rhetoric of empathy, also spotlighted are the 
concepts of tolerance and multiculturalism, which seem to be incongruous with real life. The (male or female) unmarked foil characters make various hostile statements toward the (refugee) protagonists under a threat rhetoric. These statements reveal that the refugees are variously reflected as out-groups, the source of security threats, and economic and social burdens for the host country's welfare system. The authors, thus, portray the voice of xenophobic arguments through which refugees are collectively labelled with negative stock attributions, projecting a readymade image. Reader, hence, learns to avoid damaging refugee children's self-esteem by taking care not to expose them to such discriminatory rhetoric. In conclusion, these books on Syrian civil war enable children to engage in ideological dissonance in the form of an asymmetrical portrayal of representations, social binaries, "us vs. them" polarization, which, in turn, results in the development of critical literacy.

\section{Acknowledgements}

I would like to thank Nilgün Dungan for translating the poem presented within the analysis of Text 1. I also would like to thank Simon Edward Mumford for proofreading the draft of this manuscript. Finally, I would like to thank the editors and two anonymous reviewers for their valuable feedback on a previous version of this paper and for their constructive suggestions.

\section{Works Cited}

Beauvais, Clémentine. The Mighty Child: Time and Power in Children's Literature. John Benjamins Publishing Company, 2015.

Bektaș, Habib. Tombik Balık: Denizler Hepimizin [The Plumpy Fish: We All Own the Sea]. Tudem, 2017.

Brown, Penelope, and Stephen C. Levinson. Politeness: Some Universals in Language Usage. Cambridge University Press, 1987.

Cuevas, Facundo et al. Vulnerability and Protection of Refugees in Turkey: Findings from the Rollout of the Largest Humanitarian Cash Assistance Program in the World. World Bank Group, 2019. 
Goffman, Erving. The Presentation of Self in Everyday Life. Doubleday, 1959.

Göç İdaresi Genel Müdürlüğü [Directorate General of Migration Management]. www.goc.gov.tr/gecici-koruma5638. Accessed 21 Apr. 2021.

Hess, Sabine, and Bernd Kasparek. "De- and Restabilising Schengen. The European Border Regime After the Summer of Migration." Cuadernos Europeos de Deusto, vol. 56, 2017, pp. 47-77. Hunt, Peter. An Introduction to Children's Literature. Oxford University Press, 1994.

---, and Evin Millet. "Syrian Refugees in Turkey: Insecure Lives in an Environment of PseudoIntegration." Working Paper 13, 2016, www.iai.it/sites/default/files/gte_wp_13.pdf. Accessed 21 Apr. 2021.

Meyer, Michel. "What is the Use of Topics in Rhetoric?" Revue Internationale de Philosophie, vol. 4, 2014, pp. 447-62.

Frye, H. Northrop. Myth and Metaphor: Selected Essays, 1974 - 1988. Edited by Robert D. Denham, University of Virginia Press, 1991.

Okyay, Aslı, and Jonathan Zaragoza-Cristiani. "The Leverage of the Gatekeeper: Power and Interdependence in the Migration Nexus between the EU and Turkey." The International Spectator, vol. 51, no. 4, 2016, pp. 51-66.

Onay-Coker, Duygu. "The Representation of Syrian Refugees in Turkey: A Critical Discourse Analysis of Three Newspapers." Continuum, vol. 33, no. 3, 2019, pp. 369-85.

Öztürk, Güzin. Kuș olsam Evime Uçsam [I Wish I Was a Bird and Flew Home]. Tudem, 2016. Polat, Rabia K. "Religious Solidarity, Historical Mission and Moral Superiority: Construction of External and Internal 'Others' in AKP's Discourses on Syrian Refugees in Turkey." Critical Discourse Studies, vol. 15, no. 5, 2018, pp. 500-16.

Reynolds, Kimberley. Children's Literature: A Very Short Introduction. Oxford University Press, 2011.

Reynolds, Kimberley. Left Out: The Forgotten Tradition of Radical Publishing for Children in Britain 1910-1949. Oxford University Press, 2016. 
Schlenker, Barry R. "Identity and Self-identification." The Self and Social Life. Edited by Barry R. Schlenker, McGraw-Hill, 1985, pp. 65-99.

Sezer, Çiğdem. Juju Beni Unutma [Juju, Don’t Forget Me]. Bilgi Yayınevi Çocuk Kitaplığı, 2015.

Stephens, John. Language and Ideology in Children's Fiction. Longman, 1992.

Toğral Koca, Burcu. "Syrian Refugees in Turkey: from 'Guests' to 'Enemies'?” New Perspectives on Turkey, vol. 54, 2016, pp. 55-75.

UNHCR Turkey Operational Update January 2021.

reporting.unhcr.org/sites/default/files/UNHCR\%20Turkey\%20Operational\%20Update\%20January\%202021.pdf Accessed 10 Apr. 2021.

Van Dijk, Teun A. Prejudice in Discourse: An Analysis of Ethnic Prejudice in Cognition and C onversation. John Benjamins Publishing, 1984.

Van Dijk, Teun A. "Structures of Discourse and Structures of Power." Communication Yearbook 12 . Edited by J.A. Anderson, Sage, 1989, pp. 18-59.

Van Dijk, Teun A. Racism and the Press. Routledge, 1991.

Van Dijk, Teun A. "Elite Discourse and the Reproduction of Racism." Hate Speech. Edited by R. Slayden and D. Slayden, Sage, 1995, pp. 1-27.

Van Dijk, Teun A. "Discourse Analysis as Ideology Analysis." Language and Peace. Edited by Christina Schaffner and Anita L. Wenden, Aldershot, 1995, pp. 17-33.

Van Dijk, Teun A. Ideology: A Multidisciplinary Approach. Sage, 1998.

Van Dijk, Teun A. "On the Analysis of Parliamentary Debates on Immigration." The Semiotics of Racism: Approaches in Critical Discourse Analysis. Edited by M. Reisigl and R. Wodak, Passagen Verlag, 2000, pp. 85-104.

Van Dijk, Teun A. "Ideology and discourse analysis." Journal of Political Ideologies, vol. 11, no. 2, 2006, pp. 115-40.

Van Dijk, Teun A. "Politics, Ideology and Discourse." Elsevier Encyclopedia of Language and Linguistics, Volume on Politics and Language. Edited by R. Wodak, Elsevier, 2006, pp. 728-40. 
Van Dijk, Teun A. "Critical Discourse Studies: A Sociocognitive Approach." Methods of Critical

Discourse Analysis. Edited by Ruth Wodak and Michael Meyer, Sage, 2009, pp. 62-85.

Van Dijk, Teun A. "Discourse and Migration." Qualitative Research in European Migration Studies.

Edited by R. Zapata-Barrero and E. Yalaz, Springer Open, 2018, pp. 227-45. 
[1] Book titles and examples in the analysis section were translated by the author.

\section{(c) (i) (9)}

Creative Commons Attribution-NonCommercial-NoDerivatives 4.0 International License 